\title{
Video Learning Multimedia Berpengaruh Terhadap Pengetahuan Remaja Tentang Menarche
}

\author{
Ririn Harini $^{1 *}$, Nurul Aini Rahmawati ${ }^{2}$ \\ ${ }^{I}$ Departement Keperawatan, Universitas Muhammadiyah Malang, Jalan Bendungan Sutami 188A \\ Malang 65145 \\ ${ }^{2}$ Departement Fisioterapi, Universitas Muhammadiyah Malang, Jalan Bandung No. 1Malang 65133 \\ *Corresponding author: ririn_harini@umm.ac.id
}

\begin{abstract}
ABSTRAK
Memasuki masa pubertas, anak perempuan akan mulai mendapatkan menarche atau menstruasi pertama. Biasanya saat menarche datang, mereka akan mengalami rasa cemas, takut dan juga kebingungan karena belum siap dalam menghadapi masa pubertas. Hal ini disebabkan mereka tidak pernah mendapatkan pendidikan reproduksi dini. Salah satu program promosi kesehatan dalam meningkatkan pengetahuan adalah dengan memberikan penyuluhan kesehatan dengan menggunakan video learning multimedia. Penelitian ini bertujuan untuk mengetahui efektifitas health education dengan metode video learning multimedia dalam meningkatkan pengetahuan remaja mengenai menarche. Desain penelitian ini adalah survey analitik dengan pendekatan cross sectional, sampel penelitian diambil dengan accidental purposive sampling. Masing-masing sampel akan diukur tingkat pengetahuan terhadap menarche sebelum dan sesudah diberikan health education dengan video learning multimedia. Berdasarkan hasil uji statistic dengan Wilcoxon didapatkan nilai signifikansi $0,00$ ( $\mathrm{p}>0,005)$. Dapat disimpulkan bahwa health education dengan video learning multimedia efektif meningkatkan pengetahuan remaja tentang menarche
\end{abstract}

Keywords: Pengetahuan remaja, menarche, health education, video learning multimedia

\section{PENDAHULUAN}

Kesehatan reproduksi remaja secara umum didefinisikan sebagai kondisi sehat dari sistem, fungsi dan proses alat reproduksi yang dimiliki oleh remaja berusia 10-24 tahun. Beberapa faktor yang mendasari kesehatan reproduksi remaja menjadi isu penting adalah pengetahuan remaja tentang kesehatan reproduksi masih sangat rendah, akses pada informasi yang benar tentang kesehatan reproduksi sangat terbatas, baik dari orang tua, sekolah maupun media massa. Informasi yang menyesatkan akan memicu kehidupan seksualitas remaja semakin meningkat. Kesehatan reproduksi berdampak panjang, karena status kesehatan reproduksi yang rendah akan merusak masa depan remaja (BKKBN \& UNICEF 2004).

Setiap anak ketika memasuki masa remaja akan mengalami perubahan fisik yang cepat. Anak perempuan biasanya mengalami perubahan fisik yang lebih dahulu dibandingkan anak laki-laki. Salah satu perubahan fisik tersebut adalah proses reproduksi (proses melanjutkan keturunan) yang erat hubungannya dengan perubahan fisik atau yang lebih dikenal dengan istilah pubertas. Pubertas yaitu dimulainya kehidupan seksual dewasa, periode pubertas terjadi karena kenaikan sekresi hormon gonadotropin oleh hipofise yang perlahan. Dimulai pada tahun ke-8 dari kehidupan dan mencapai puncak pada saat terjadi menstruasi pada usia 11-16 tahun (Syaifuddin, 2006). 
Menarche sering menimbulkan berbagai perubahan fisik maupun psikis pada anak. Perubahan fisik yang terjadi bisa menyebabkan anak mengalami dampak yang negatif seperti malu, cemas dan menghindar dari pergaulan temantemannya, sehingga berdampak buruk bagi perkembangannya. Hal ini disebabkan karena tingkat pengetahuan anak yang kurang tentang menarche.

Salah satu program kesehatan reproduksi remaja yang dibuat oleh pemerintah Indonesia adalah dengan pemberian pendidikan kesehatan reproduksi. Pemberian pendidikan reproduksi perlu dilakukan karena masalah tentang kurangnya pengetahuan remaja mengenai kesehatan reproduksi masih sangat rendah. Budaya "tabu" dalam pembahasan seksualitas menjadi suatu kendala kuat dalam hal ini. Pemberian pendidikan kesehatan reproduksi dapat diberikan secara langsung maupun dengan menggunakan media. Penggunaan media dalam penyuluhan kesehatan akan membantu memperjelas informasi yang diberikan, karena dapat lebih menarik, lebih interaktif dan dapat mengatasi batasan ruang, waktu dan indera manusia. Pentingnya penggunaan media adalah untuk peningkatan pengetahuan keterampilan, sikap dan perilaku yang merupakan hasil dari proses belajar yang keberhasilannya ditentukan oleh efektivitas media pembelajaran dan efektivitas penggunaan media penyuluhan ditentukan oleh banyaknya indra yang digunakan. Dibutuhkan suatu inovasi, agar minat belajar siswi tentang pendidikan reproduksi dini semakin tinggi, maka diperlukan sesuatu yang dapat membuat mereka tertarik salah satunya video learning multimedia yang sedang digemari dikalangan remaja.

Penggunaan media pembelajaran yang kurang menarik dan kurang tepat terhadap materi yang disampaikan dapat berdampak negatif. Masalah tersebut dapat teratasi apabila dapat memilih strategi dan media pembelajaran yang tepat. Saat ini, media lembar balik merupakan media yang sudah dikenal oleh banyak orang karena banyak digunakan dalam pekerjaan dan dapat digunakan juga dalam proses pembelajaran, karena lembar balik merupakan salah satu media grafis yang dapat menyajikan pesan atau materi secara bertahap. Sedangkan pemanfaatan teknologi multimedia dalam dunia pendidikan bukanlah merupakan hal yang baru. Fakta menunjukkan bahwa, banyak penelitian yang membuktikan unsur-unsur multimedia dapat membantu siswa untuk melakukan proses visualisasi. Multimedia mampu mendukung proses interaksi dan juga membantu interaksi kelompok pada pembelajaran siswa secara aktif, terutama dalam sistem pembelajaran jarak jauh. Semua ini membuktikan bahwa multimedia sangat cocok digunakan dalam proses belajar mengajar. Disamping itu penggunaan media interaktif mampu menarik perhatian serta lebih mudah dipahami dibandingkan dengan bahanbahan statik atau tanpa suara (Ali, 2011).

Berdasarkan hal tersebut peneliti tertarik untuk melakukan penelitian yang bertujuan untuk mengetahui efektifitas health education dengan metode video learning multimedia dalam meningkatkan pengetahuan remaja mengenai menarche.

\section{METODE}

Penelitian yang dilakukan merupakan penelitian survey analitik dengan pendekatan cross sectional, yang bertujuan untuk mencari hubungan antara pemberian health education dengan tingkat pengetahuan tentang menarche pada remaja. Populasi pada penelitian ini adalah siswa SDN 1 Pakisaji Kelas $5 \& 6$ yang berjumlah 112 orang, dan sampel diambil dengan cara accidental purposive sampling, yaitu mengambil sampel secara keseluruhan dari jumlah populasi. Penelitian ini dilakukan dengan menggunakan metode pembelajaran Video Learning Multimedia, dan tingkat pengetahuan sampel tentang menarche 
akan diukur sebelum dan sesudah pemberian metode pembelajaran video learning multimedia. Instrument yang digunakan dalam penelitian ini adalah kuesioner. Analisa data dilakukan dengan menggunakan uji statistic Wilcoxon.

\section{HASIL DAN PEMBAHASAN}

Hasil dari Health education berbasis video learning multimedia yang telah dilakukan pada siswa-siswi kelas 5-6 SDN 1 Pakisaji Malang adalah efektif untuk meningkatkan pengetahuan remaja tentang menarche di SDN 1 Pakisaji. Efektivitas tersebut didapatkan berdasarkan hasil uji Wilcoxon signed rank test dengan nilai a signifikan $0.000<0.05$ yang tertera pada tabel 1 berikut :

Table 1 Signifikansi tingkat pengetahuan sebelum dan sesudah pemberian Health Education

\begin{tabular}{|c|c|}
\hline & 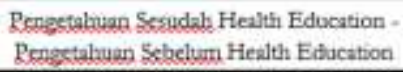 \\
\hline $\bar{z}$ & $-4.810^{4}$ \\
\hline $\begin{array}{l}\text { Asymp, Sig. (2- } \\
\text { tailed) }\end{array}$ & .000 \\
\hline
\end{tabular}

Hasil penelitian ini sejalan dengan hasil penelitian yang dilakukan oleh Luluk \& Erik (2014), yang menyatakan bahwa penggunaan media video dalam Pendidikan kesehatan memiliki pengaruh terhadap perubahan sikap dan perilaku seseorang. Menurut Munir (2013), animasi merupakan kegiatan menggerakkan gambar menjadi seolaholah hidup, animasi mampu menjelaskan suatu konsep atau proses yang sulit dijelaskan dengan media lain sehingga menimbulkan motivasi untuk siswa ikut berperan aktif dalam proses pembelajaran.

Efektifitas health education yang telah dilakukan juga tidak lepas dari faktor internal maupun eksternal yang mempengaruhi pengetahuan remaja siswasiswi SDN 1 Pakisaji, selain metode yang telah peneliti gunakan yaitu video learning multimedia. Hasil penelitian mengungkapkan bahwa faktor internal pertama yang mempengaruhi efektivitas health education berbasis video learning multimedia ini adalah pengalaman. Notoatmodjo (2012) mendefinisikan bahwa pengalaman dapat digunakan untuk memperoleh suatu kebenaran pengetahuan yang didapat.

Faktor internal yang kedua adalah usia, sampel dalam penelitian ini berusia 11-12 tahun. Usia anak 11-12 tahun tersebut memiliki kemampuan logika yang baik sesuai dengan teori perkembangan kognitif Jean Piaget, dimana anak ada dalam proses operasional konkrit. Tahapan perkembangan kognitif ini ada pada anak usia 7-12 tahun, egosentris anak mulai berkurang sehingga rasionalitas menjadi lebih baik dan dapat lebih mudah menerima pengetahuan baru meskipun belum dapat memecahkan masalah yang abstrak (Luklukaningsih, 2014). Oleh karena itu video learning multimedia sangat berperan untuk menunjang perkembangan kognitif anak dalam bentuk media audiovisual.

Pendidikan adalah faktor internal berikutnya yang ditekankan oleh Notoatmodjo (2012). Pengetahuan mengenai kesehatan reproduksi dasar yang telah didapatkan oleh remaja sebelum pemberian health education dengan video learning multimedia membuat sampel dapat menerima dengan sangat baik bahkan mencetuskan rasa keingintahuan lebih dalam. Berdasarkan hal tersebut maka dapat dikatakan siswa maupun siswi yang sudah maupun yang belum mengalami menarche telah mengetahui, memahami dan diharapkan dapat siap untuk mengoptimalkan pertumbuhan dan perkembangannya saat ini khususnya menarche.

Faktor yang berasal dari luar atau yang biasa disebut faktor external juga dapat mempengaruhi keefektifitas health education berbasis video learning multimedia. Pengaruh orang lain adalah faktor external utama yang disebutkan Notoatmodjo (2012), dimana seseorang yang dianggap berarti akan mempengaruhi dan membawa perubahan langsung pada 
individu. Pengaruh teman sebaya sangat diperlukan dalam proses perkembangan menarche, pada usia 11-12 tahun anak merasa lebih tertarik dan memahami persiapan menarche maupun berbagi pengalaman menarchenya. Teman sebaya akan sangat berpengaruh pada proses pertukaran informasi antar individu atau biasa disebut dengan proses knowledge sharing sehingga akan merubah persepi, emosional dan pemahaman terhadap konsep serta identitas diri penerima informasi tersebut (Smith et al., 2006).

Media sosial dan budaya adalah faktor external berikutnya yang disebut Notoarmodjo (2012) akan mempengaruhi pengetahuan individu. Kebudayaan akan memberikan warna sikap dan paradigma yang berbeda Budaya akan memberikan corak pengalaman tersendiri, sehingga akan mempengaruhi individu dalam menerima informasi baru. Dan media sosial akan mendukung untuk pembentukan opini dan kepercayaan seseorang terhadap sesuatu, khususnya bagi anak usia 11-12 tahun yang fungsi kognitifnya semakin berkembang. Media sosial akan memberikan sugesti tertentu, baik yang berkonotasi buruk ataupun yang baik. Sehingga dari paparan hasil penelitian yang telah dianalisa diatas dapat ditarik kesimpulan bahwa health education berbasis video learning multimedia sangat berpengaruh secara signifikan terhadap keefektifan dalam penyampaian imformasi kesiapan menghadapi menarche dan dapat menurunkan tingginya insiden dan stressor pada remaja yang mengalami menarche

\section{KESIMPULAN}

Penelitian ini dapat diambil kesimpulan bahwa health education dengan video learning multimedia efektif untuk meningkatkan pengetahuan remaja tentang menarche di SDN 1 Pakisaji.

\section{REFERENCES}

Ali, I.T. (2011). Analisis Hubungan Implementasi Multimedia Pada Learning Management System Terhadap Kemampuan Mahasiswa Dalam Penguasaan Materi Pembelajaran. Jurnal Sains dan Teknologi, 10 (1), 1-7.

BKKBN dan UNICEF. (2004).Remaja Hari ini adalah Pemimpin Masa Depan. Jakarta : BKKBN Pusat

Luklukaningsih, Z. (2014). Anatomi Fisiologi Dan Fisioterapi. Yogyakarta : Nuha Medik

Luluk, dan Erik. (2014). Pengaruh Penyuluhan Kesehatan Dengan Media Video Terhadap Pengetahuan Dan Sikap Personal Hygiene Siswa SD Negeri 1 Kepek Pengasih Kulon Progo. Program studi ilmu keperawatan sekolah tinggi ilmu kesehatan aisyiyah yogyakarta.

Munir. (2013). Multimedia Konsep dan Aplikasi dalam Pendidikan. Bandung : Alfabeta

Notoatmodjo, S. (2012). Promosi Kesehatan Dan Perilaku Kesehatan. Jakarta : Rineka Cipta

Smith A, Jones J, Cavanaugh C, Venn J, Wilson W. (2006). Effect of interactive multimedia on basic clinical psychomotor skill performance by physical therapy student. Journal of Physical Therapy Education 20:61-67

Syaifuddin. (2006). Anatomi Fisiologi Untuk Mahasiswa Keperawatan Edisi 3. Jakarta : EGC 